\title{
Institutional trust in the Croatian post-socialist context ${ }^{1}$
}

\author{
Antonija Čuvalo² \\ Faculty of Political Science, University of Zagreb, Croatia
}

\section{doi:10.5937/comman1326145C}

Summary: The purpose of this article is to determine the position of trust in media in relation to trust in other political institutions in Croatia. The main assumption is that institutional trust is a multidimensional phenomenon, which is as such evaluated by citizens who are able to distinguish different institutions and evaluate them according to individual performance. Furthermore, the article aims to define the determinants of each underlying dimension of institutional trust. The study draws from data gathered within the project Trust in Media 2009, on a nationally representative sample for Croatia $(n=1000)$. First, dimensions of trust were defined by the method of principal components (Varimax). The results confirmed the multidimensionality of institutional trust. Five dimensions (sub-scales) of institutional trust were extracted: trust in party and business elite, trust in state institutions, trust in cultural elite, trust in EU and trust in media. Results did not confirm the hypothesis on trust in media as a completely independent dimension of institutional trust. Second, inter-correlation and regression analysis was applied in order to determine trust in different dimensions of institutional trust. Frequency of media use proved to be the best predictor of institutional trust. Frequency of television viewing has a positive effect on trust in state institutions, while there was no evidence of the effect of reading daily newspapers on trust.

Keywords: trust in media, trust in social and political institutions, dimensions of trust, post-socialist societies, media and democracy

The main purpose of this article is to determine the position of trust in media in relation to trust in other political institutions in Croatia. Trust is in contemporary social thought considered important as an essential element of the socio-cultural potential of each society (Nikodem \& Črpić, 2011; Trzun,

\footnotetext{
1 Research for this paper was conducted within the project 'Media culture in contemporary Croatia: media pluralism and media politics' at the Centre for Media and communication research, Faculty of political science, University in Zagreb, funded by the Ministry of Science, Education and Sport.

2 antonija.cuvalo@fpzg.hr
} 
2012). Trust in a system's institutions is at the same time a basis and a condition for its effectiveness and represents the core element of its legitimation (Coleman, 2012; Gross et al., 2004; Khodyakov, 2007; Mishler \& Rose, 2001; Šporer \& Sekulić, 2011; Trzun 2012). Trust is considered important for maintaining social order and social cohesion especially in 'risky' (Beck 1992; Giddens 1990) and 'large-scale' complex modern societies where people, groups and institutions are continuously in situations where they have to make 'risky decisions' (Kohring \& Matthes, 2007; Gross et al., 2004). As an important element of a system's legitimation, the issue of trust is especially important in transitional societies where, as many empirical studies show, distrust in institutions, cynicism or strong scepticism pervade (Catterberg \& Moreno, 2005; Dmitrova-Grajzl \& Simon, 2010; Luengo \& Maurer, 2009; Mishler \& Rose, 2001; Pehlivanova, 2009; Rimac \& Štulhofer, 2004; Trzun, 2012; Šalaj, 2006). According to American political scientists William Mishler and Richard Rose (2001), trust is learned and linked to some level of experience through lifetime learning experiences. They argue that contemporary institutional trust is a product of past political trust modified by recent performance experiences.

The main focus here is impersonal trust or trust in institutions and not (strong or weak) interpersonal trust (Khodyakov, 2007; Mishler \& Rose, 2001; Newton \& Norris, 1999). Kenneth Newton and Pippa Norris (1999, versus for example Putnam, 2000) argue that in modern societies, social and political stability depends on institutional trust rather than on trust in individuals and the quality of interpersonal relations (similar in Khodyakov, 2007 and Mischer \& Rose, 2001).

Numerous authors have been drawing attention to the continuous decline of trust in political institutions, including trust in media in developed Western democracies (Cook \& Gronke, 2001; Golding et al., 2012; Gross et al., 2004; Quandt, 2012, Newton \& Norris, 1999; Norris, 1999; Van Zoonen, 2012), and relatively low levels of trust in Eastern and Southeastern European postsocialist societies (Mishler \& Rose, 2001; Rimac \& Štulhofer, 2004; Trzun, 2012). However, this decline is neither homogenous nor unidirectional (Cook \& Gronke, 2001; Šporer \& Sekulić, 2011). Previous empirical studies (Cook $\&$ Gronke, 2001) on the dimensionality of institutional trust within the established democratic framework showed that media are usually evaluated as a part of civil society (Lipset \& Schneider, 1987), the private/non-profit sector (Newton \& Norris, 1999) or the opposition (Dohring, 1992). This is opposite to the situation in post-socialist countries, where studies from the first decade of the transitional period revealed one general dimension of institutional trust/ distrust (Mishler \& Rose, 2001; Rimac, 2000). 
Croatia is usually classified as a Central and Eastern or Southeastern European country and is a country of relatively low institutional trust and social trust (Baloban \& Rimac, 1999; Nikodem \& Črpić, 2011). Various studies on trends in institutional trust in Croatia conducted since the 1990s also reveal its dynamic and multidimensional nature (Baloban \& Rimac, 1999; Rimac, 2000; Šporer \& Sekulić, 2011). Mishler and Rose (2001) point out the possible difference in the dimensionality of institutional trust in new democracies when compared to established democracies where citizens:

"...may be capable of distinguishing the contributions of different institutions to overall government performance, [whereas] citizens in new democracies have difficulty making fine-grained distinctions, about institutions [with] which they have so little familiarity or experience" (2001: 42-3).

Nevertheless, trust in media can be analysed as an aspect of institutional trust, which is considered as an important indicator of the social system performance and satisfaction with the political system, providing a basis for their legitimation (Šporer \& Sekulić, 2011). Media as social institutions play an important role in democratic societies as intermediaries between representatives and the public. According to British sociologist and media scholar John B. Thompson (1995), mass media had an important role in the development of institutions, through its various genres, people's perceptions, beliefs and behaviours, (Thompson, 1995). Modern democracies "rely upon informed consent of citizens" and "citizens are expected to be aware of polices and events that are likely to affect them, and capable of expressing occasional preferences at the ballot box" (Coleman, 2012: 35) .

The broad framework as well as the rationale of my research question refers to the role of the Croatian media in a democratic political system, particularly regarding trust in political institutions. The aim is to reveal the underlying dimensions of institutional trust and to determine the role of trust in media in relation to trust in institutions. The main assumption is that institutional trust is a multidimensional phenomenon, which is as such evaluated by citizens who are able to distinguish different institutions and evaluate them according to individual performance. To answer this question, the position of trust in media in relation to institutional trust will be analysed based on data gathered within the project Trust in media on a nationally representative sample for Croatia $(\mathrm{n}=1000)$.

Even though trust is considered as a necessary condition for the functioning of democratic systems, distrust also represents the core element of democracy, in the form of legitimate criticism (Catterberg \& Moreno, 2005; Moy et al., 2005; Šalaj, 2006). Importance of trust for a democracy was also emphasized by Berto Šalaj (2006), who reminds us that the idea of modern democracy is based on political distrust in traditional institutions 


\section{Trust in media as a dimension of institutional trust}

In contemporary Western political thought, trust in media is related to trust in democratic political institutions, democracy and democratic values as the basis for the functioning of the democratic system (Mishler \& Rose, 2001). It is considered important for civic engagement, healthy and stable democracy (Jones, 2004; Moy et al., 2005).

The significance of trust in communication media in democratic political systems is based on the assumption of the effect of the media on citizens' political behaviour, including political participation (Kohring \& Mathes, 2007; Moy et al., 2005; Norris, 1999; Norris \& Ingelhart, 2009; Newton \& Norris, 1999; Pehlivanova, 2009). Underlying such research is the acknowledgment that news media may be at least one of the influences on social (interpersonal trust), political and institutional trust and on political participation (Gross et al., 2004). However, there is no agreement between researchers about the nature of media effects on political attitudes and behaviour. The contribution of media to trust in institutions is analysed in literature through attempts to answer the question regarding the relationship between the exposure to mass communication and trust in political institutions. Relying on the 'cultivation theory', the proponents of the media malaise approach, argue about the negative effect of media on trust in political institutions (Luengo \& Maurer, 2009: 40; Pharr \& Putnam, 2000).

Based on numerous empirical studies, the approach known as theories of political mobilisation (further developed in the virtuous circle theory by Norris \& Ingelhart, 2009) opposes the main argument of the media malaise theory (Luengo \& Maurer 2009: 40; Norris \& Ingelhart, 2009). Both media malaise as well as political mobilisation presuppose the significant role of media on trust in political institutions, but they differ in the definition of the direction of this effect. Advocates of the political mobilisation approach exhibit ample empirical evidence which shows the positive correlation between regular consumption of news media and interest in politics, political knowledge, civil engagement and institutional trust. Exposure to sensationalistic content is, within this framework, related to political dissatisfaction, cynicism and alienation (Luengo \& Maurer, 2009; Norris \& Ingelhart, 2009).

An important variable for the explanation of the relationship between political communication and political trust is the character of media content. Michael J. Robinson (1976 cited in Gross et al., 2004: 51) was one of the first scholars who emphasises that the interpretative, negative and anti-institutional 
character of political coverage on television increases political cynicism. Regarding the impact on trust of the interest in media coverage of politics, an interesting point is made by Luengo and Maurer (2009). Although the vast number of empirical studies show that regular readers - compared to non-readers - of daily informative press express a lower level of political disaffection (measured by trust in the national parliament) there was no evidence for the thesis that watching TV news has a similar positive effect (Luengo \& Maurer, 2009: 41). In order to fill this gap, political communication scholars Oscar Luengo and Marcus Maurer (2009: 42), following Almond and Verba's argumentation, suggest that it would be useful to control the impact of political culture, the characteristics of the political system and journalistic culture in order to better explain the relationship between political communication and civic engagement (which is considered as an indicator of media system quality performance). Their analysis of European countries show the lowest level of exposure to political media content in Central and East European countries, where the lowest level of political (institutional) trust was also measured. However, this pattern did not occur uniformly in the old members of European Union where there were significant differences between Western, Southern and Northern countries (Luengo \& Maurer, 2009: 44).

Media as social institutions are at the same time important societal 'autonomous expert systems' (Giddens, 1990; Kohring \& Matthes, 2007) with a significant role in democratic societies as intermediaries between representatives and the public. Media provide citizens with information, necessary for coping successfully with everyday activities and demands. Media as 'knowledge institutions' or 'autonomous expert systems' depend on trust to be considered as relevant (Van Zoonen, 2012). As members of audiences, we cannot control the effectiveness of media as 'knowledge institutions', due to our lack of knowledge, time and money (Kohring \& Matthes, 2007; Tsfati \& Cappella, 2003). That is to say, we have to trust them.

When I analyse the role of the media regarding trust in political systems, it is important to know how distinct the perception of trust in media is from trust in political institutions. In order to answer this question, American mass communication scholar Timothy E. Cook and political scientists Paul Gronke (2001) analysed data regarding trust in institutions for each of the twenty years of the GSS from 1973 to 1998 (General Social Survey of the National Opinion Research Center at the University of Chicago). They tested five theoretical models of the dimensionality of institutional trust: 1) non-dimensionality; 2) 
one-dimensional model; 3) Lipset-Schneider's bi-factorial model, where one dimension comprises trust in press and television as indicators of trust in media, while the second comprises trust in political institutions; 4) Newton-Norris' two-dimensional model, with the first dimension of trust in public institutions (trust in parliament, legal system, police, civil service and armed forces), and the second dimension of trust in private and non-profit institutions (the civil service, the education system, the church, major companies, the press and trade unions), where trust in media is an element of trust in private and non-profit institutions; and 5) Dohring's three-factorial model, where one dimension is trust in institutions of social order (economy, religion, health insurance, science and armed forces), the second dimension is trust in political institutions (parliament, executive branch and supreme court) and the third dimension is trust in opposition (unions, educational leaders, print and television). Results revealed a two-dimensional structure of institutional trust, where trust in media follows a different logic from trust in other institutions (Cook \& Gronke, 2001).

In all four studies (Cook \& Gronke, 2001; Dohring, 1992; Lipset \& Schneider, 1987; Newton \& Norris, 2000), the theoretical and empirical models tested in Western democracies (non-dimensional and one-dimensional were hypothetical models) showed that trust in media is independent from trust in political institutions. This is similar to Mishler and Rose's (2001) argument regarding undifferentiated trust in political institutions at the beginning of the transitional process. In Croatia, the dimensions of institutional trust were examined in a few studies published at the end of the first decade of the democratic transition (Baloban \& Rimac, 1999; Rimac, 2000) and more recently between 2000 and 2010 (Šporer \& Sekulić, 2011). Croatian sociologist Ivan Rimac (2000) analysed summarised data on trust in institutions in Croatia, gathered as a part of the project Faith and moral in 1997 and the European Value Survey (1999). Rimac discerned the one-dimensional structure of trust in measured institutions - church, army, educational system, print, trade unions, police, parliament, public service, welfare, EU, UN, NATO, health system, judiciary and big companies. His study shows that trust in media followed the same logic as trust in other institutions.

More recent studies (Šporer \& Sekulić, 2011) carried out in the 2000s (the first wave was in 2004 and the second, in 2010) show that trust in media such as print and television, actually increased while trust in some other institutions, such as the church, government and parliament, dropped significantly. Croatian sociologists Željka Šporer and Duško Sekulić relate this raise in trust 
in media to the role that Croatian media (especially print media) have played since the end of 2009 in revealing political corruption. Furthermore, within their study, trust in media was evaluated as independent from trust in other institutions, which could indicate a significant (but perhaps temporary) differentiation between perceptions of media performance and perceptions of other political and social institutions. My study deals with data gathered at this critical point regarding trust in Croatian media, before the peak in media coverage of political corruption (two months after Prime Minister Sanader resigned from this position without any explanation, and almost one year before he was arrested and indicted for corruption).

\section{Study design}

In order to determine the position of trust in media in relation to trust in other political institutions in Croatia, I analysed data gathered in autumn 2009 as part of the project Trust in Media conducted by the Faculty of political science, University of Zagreb. Data were gathered by the method of an in-house (pen and paper) questionnaire on the nationally representative sample (according to age, gender, education and region) of 1,000 adult Croatian citizens $(18+)$. Data from this survey are used for the purposes of this paper in order to determine the role of trust in media. First, patterns of inter-correlations between trust in media and trust in other institutions are analysed in detail. Furthermore, determinants of trust in media are assessed through the analysis of correlations between media use and trust in media and respective institutions. Finally, an analysis of socio-demographic determinants of trust in media is presented.

Empirical and theoretical models tested in Western democracies suggest that trust in media is a dimension independent from trust in other political institutions (Cook \& Gronke, 2001). Based on these respective cases (Cook \& Gronke, 2001; Mishler \& Rose, 2001) and on recent assessments of the Croatian media system (Peruško, 2011), the first assumption is that evaluations of political institutions are more differentiated (multidimensional) than in previous studies conducted in Croatia where a one-dimensional structure was measured (H1). Additionally, the second assumption is that trust in media in Croatia is an independent dimension, different from trust in political institutions (H2). Regardless of some problems that still occur, media are regulated according to democratic standards, and the mainstream media do not question democracy as a political regime (Peruško, 2011). Based on this, we could as- 
sume that media would receive a better evaluation than political institutions, which are faced with deep crises (resignation of prime minister Ivo Sanader indicted for corruption, corruption affairs and economic recession).

Based on the abovementioned empirical studies (Gross et al., 2004; Luengo \& Maurer, 2009), a third assumption is made, which posits a higher level of trust in political institutions among those who read daily newspapers, than among those who rely mostly on television (H3). Furthermore, as patterns of the relationship between socio-demographic indicators (age, income, education, settlement) and institutional trust in Western democratic societies differ from respective patterns in Central and Eastern European countries (Mishler \& Rose, 2001; Šporer \& Sekulić, 2011), we additionally tested correlations between dimensions of institutional trust and respective socio-demographic indicators. It is important to note that empirical studies on the relationship between socio-demographic variables and trust revealed strong correlations for many developed Western societies, while in Central and Eastern European countries this relationship was weak (Mishler \& Rose, 2001; Šporer \& Sekulić, 2011). The following indicators - which were confirmed as important for explaining institutional trust in various studies in established democracies (Mishler \& Rose, 2001; Sztompka, 1999) - were analysed: age, self-reported economic position as an indicator of wealth and educational level. Based on this difference, we assume that socio-demographic indicators are not correlated with institutional trust. In brief, the following hypothesis will be tested:

$\mathrm{H} 1$ : Institutional trust is a multidimensional phenomenon.

$\mathrm{H} 2$ : Trust in media is independent from trust in other institutions.

$\mathrm{H} 3$ : The frequency of reading daily newspapers is significantly and positively correlated with institutional trust, while the frequency of watching television has a negative effect on institutional trust.

H4: Socio-demographic indicators have no effect on institutional trust.

The instrument used for measuring trust in institutions as a part of the Trust in media 2009 project was comprised of 19 items, covering state and political institutions (government, parliament, president, Croatian army and police, parties and preferred party), public institutions (educational institutions), civil sector (NGOs, trade unions) international organisations/entities (EU, international media) and national media, together with some important social stakeholders 
from different sectors (party leaders, leader of preferred party, top managers, scientists and journalists). Respondents were asked to evaluate each of these institutions on a 5-point scale, where 1 indicates the highest distrust and 5 indicates the highest level of trust, by answering the question: "How much do you trust in each of the following institutions?"

Furthermore, trust in different types of media (TV, radio, daily newspapers, internet and weekly newspapers) is analysed in order to explain in more detail the dimension of trust in media and other institutions.

An exploratory factor analysis (method of principal components) was conducted on $24^{4}$ items in total. ${ }^{5}$ These items could be divided into two broad categories: first, trust in major institutions, and second, trust in major stakeholders. The first category comprises the following items: trust in state and public institutions (government, parliament, police, army and educational institutions), civil society institutions (trade unions, NGOs) trust in institutions of representative democracy (political parties), trust in the European Union, foreign media and church. The second category (trust in major stakeholders) comprises trust in the leader of the party they voted for, trust in business elite and trust in honoured intellectuals, journalists and scientists. In order to find the best predictors of different types of institutional trust, hierarchical multiple regression was applied (backward) with dimensions (sub-scales) of trust (trust in party and economic elite, trust in state institutions, trust in cultural and political elite, trust in EU and trust in media) as dependent variables and frequency of media use as independent variables. Media use was measured by a 5-point scale, where 1 indicates very rare usage and 5 indicates a high frequency of media use. It is important to know that this scale does not show how much respondents use media for gathering political information. Although we do not have information for each analysed medium about the percentage of use for gathering political information, it may be indicative that only $7 \%$ of respondents from our sample mentioned that they watch political programmes on TV (Car, 2010).

\footnotetext{
${ }_{4}^{4}$ Trust in the preferred party was excluded from the final solution in order to get a better solution according to relevant tests.

5 There were some important reasons from a theoretical point of view for the exclusion of trust in social and political stakeholders from this analysis in order to eliminate more contingent and performance-based evaluations related to social stakeholders (Moy et al., 2005; Newton \& Norris, 1999), and to ensure that we are measuring general trust in media and other institutions. These two models of exploratory factor analysis (one with social stakeholders included and one with social stakeholders excluded from the analysis) were compared according to relevant tests (Determinant, Kaiser-Meyer-Olkin Measure of Sampling Adequacy, Bartlett's test of Sphericity, Residuals computed, Cronbach's Alfa), and due to better results on all tests, social stakeholders were included in the final analysis and presented here.
} 
Hierarchical multiple regression was also applied to test socio-demographic variables (age and educational level) as predictors of each dimension of institutional trust.

\section{Results}

When we take a closer look at the level of trust respondents (Table 5, Annexe) have in Croatian media compared with trust in other analysed social and political institutions, the results of the study imply that the respondents are sceptical towards all measured institutions (mean values from 2.5-3.5). Trust in national media (2.78) and journalists (2.73), as well as trust in most of the analysed institutions falls in this same category. Trust in media and journalists is lower than trust in church (3.44), which is evaluated as the most trustworthy institution, followed by trust in scientists, educational institutions, the Croatian army, intellectuals and party leaders, but it is higher than trust in police, top managers, civil sector institutions (NGOs and trade unions), international institutions (global media and European Union), political parties and state institutions (preferred party, president and political parties in general).

Five independent factors (Varimax solution, Table 6) were extracted that explained $47.36 \%$ of the variance (Determinant $=.008, \mathrm{KMO}=.876$; Bartlett's test of sphericity: $\left.\lambda^{2}=4746,707, d f=253, p<.000\right)$. The first two factors each accounted for approximately $11 \%$ of the explained variance. The third factor accounted for approximately $10 \%$ of the variance, the forth for $9 \%$ and the fifth for approximately 6\%. The first dimension (Cronbach's alpha=.719) of institutional trust is related to trust in party and business elite (trust in the leader of the party they voted for, trust in business elite, trust in political parties in general, trust in government and parliament, trust in radio and weekly magazines). The second dimension (Cronbach's alfa=.616) of institutional trust is related to trust in state institutions (police, army, government, parliament and television). Church was excluded from this scale because when deleted, Cronbach's alpha was raised. The third dimension (Cronbach's alfa=.707) of institutional trust refers to trust in political and cultural elite (president, scientists, honoured intellectuals, journalists and NGOs). The fourth dimension is related to trust in the $E U$ (Cronbach's alfa=.617). Even though these dimensions comprise conceptually different items (trust in the EU, trust in foreign media, trust in NGOs and trade unions and trust in the educational system), the factor loadings show that trust in the EU has the highest score in this dimension. The fifth dimen- 
sion (Cronbach's alfa $=.580$ ) is related to trust in media (daily newspapers, radio, weekly magazines, internet and daily newspapers).

According to this final solution with the five independent sub-dimensions of institutional trust, we cannot confirm the first hypothesis (H1) about trust in media as independent from trust in political institutions. Consequently, the second assumption (H2) about trust in media as an independent dimension of institutional trust was not confirmed. In fact, trust in television is evaluated with a similar logic as trust in state institutions (police, army, parliament, government and church), while domestic media in general and journalists are evaluated with a similar logic as the president, comprising the third dimension (trust in political and cultural elite). This third dimension of institutional trust (trust in political and cultural elite) seems the most similar to Dohring's (1992) oppositional factor, but in the Croatian case the institution of president is perceived close to the cultural elite and civil sector (scientists, journalist, domestic media and NGOs). It is important to note that in that period the president was Stjepan Mesić, whose political orientation is closer to the opposition, while the ruling party (parliament majority and prime minister) was HDZ, which represents the centre-right political option (Peruško, 2012).

This five-dimensional solution is not consistent with the models tested by Cook and Gronke (2001) and differs from the analysis provided by Rimac (2000), who extracted a one-dimensional structure of institutional trust in Croatia. Despite differences between data presented in Rimac (2000) and our data from 2009 analysed in this paper, we cannot confirm that trust in media is independent from trust in political institutions. Nevertheless, results show that after two decades of transition, political trust in Croatia is still not completely independent of trust in media. According to Mishler and Rose (2001), this may indicate that Croatian citizens still have difficulty making distinctions about different institutions. Consequently, the second assumption (H2) about trust in media as an independent dimension of institutional trust was not confirmed.

Our data showed that Croatian citizens rely mostly on television as a source of information. $57 \%$ use television regularly, followed by radio $(49.8 \%)$ and internet $(32.9 \%)$. Less than $30 \%$ (Table 1 ) of our sample read print media regularly (newspapers, magazines and weekly magazines). At the same time, they evaluated radio as the most trustworthy medium, followed by the internet and television, while print media were evaluated as the least trustworthy. The internet had the highest share of those who find this medium trustworthy compared to other media. Magazines and newspapers represented the highest 
share of those who distrust particular media, while radio and television had the smallest share (Table 2, Annexe). A high level of trust in the internet can at least in part be explained by the interactive nature of the medium and media use (Čuvalo, 2011). Regarding the high level of trust in radio, a useful remark is made by Croatian sociologists Gordan Črpić and Mirko J. Mataušič (1999) who also discern the highest trust in (local) radio stations. They explained this based on certain characteristics of Croatian local radio stations (higher share of relevant and prompt local news, higher level of flexibility and familiarity with their audiences).

Hierarchical multiple regression analysis was applied to determine the best predictors of each of the tested dimensions (sub-scales) of institutional trust (trust in political and business leaders, trust in state institutions, trust in cultural and political elite, trust in the EU and trust in media). Our regression model (backward) tested the impact of the frequency of consumption of television, radio, daily newspapers, weekly magazines and internet on each dimension (sub-scale) of institutional trust (Table 9). Regarding trust in party and business elite, media usage (television, radio, internet, daily newspapers and weeklies) explained $6 \%$ of the variance. Internet usage proved to have a negative effect on trust in party and business elite, while consumption of radio and weekly magazines has a positive effect on trust in media. TV and internet usage proved to be the best predictors of trust in state institutions, explaining $7 \%$ of the variance. Frequent watching of TV had a positive effect on trust, while frequent internet usage had negative effect. Trust in cultural and political elite was best explained by the frequency of TV usage ( $6 \%$ of the variance explained by the model). Media usage (TV and internet, both with a positive effect) proved also to be a small but significant predictor of trust in the EU $(3.8 \%$ of the variance explained by the model). Frequency of radio, internet, daily newspapers and weekly magazine consumption explained $8.6 \%$ of the variance of trust in media. Consumption of radio, newspapers and weekly magazines all have a significant positive effect on trust in media, while frequency of radio listening had the strongest (positive) effect.

The results did not confirm the third assumption (H3) about the positive effect of the frequency of reading newspapers on trust and the negative effect of the frequency of watching television. Quite the opposite, television viewing had a positive effect on trust in each tested dimension of institutional trust except on trust in media, while there was no evidence of the effect of reading daily newspapers on trust. Internet usage seems more important than the regu- 
lar reading of newspapers for institutional trust, but with a negative effect on trust in state institutions and trust in the elite. Nevertheless, media usage was confirmed as the best predictor of trust in institutions.

A closer look at the relationship between socio-demographic indicators and scales of media use (Table 10) shows that women watch significantly more television than men, yet this correlation is not strong. The relationship is similar between the frequency of radio listening and economic position. Age, educational level and economic position are all in significant correlation with the frequency of usage of all print media. Older respondents read print media more frequently than younger ones. The opposite situation is seen when internet users are concerned. The socio-demographic profile of internet users reveals strong indices of the digital divide in Croatian society. Even though gender is the weakest determinant of internet usage $(\mathrm{r}=.-120 ; \mathrm{p}>.05)$, the correlation is significant. Apart from gender and age, internet usage is determined by educational level ( $r=.-395 ; \mathrm{p}>.05)$ and economic position ( $\mathrm{r}=.-395 ; \mathrm{p}>.05)$.

Wealth (self-reported economic position) has a significantly positive correlation to trust in media and a significantly negative correlation to trust in state institutions (Table 8). At the same time, educational level has a negative effect on trust in party, business, political and cultural elite, but it is not significant in explaining trust in media and state institutions (Table 7). Age was confirmed as a predictor of trust in party and political elite, in political and cultural elite and in state institutions (Table 7). Older respondents were more trustful, but a higher educational level had a negative effect on trust in major political, cultural and business stakeholders. Regarding trust in media, age proved to be a small (1.6\% of the variance explained) but significant predictor of that respective dimension with a positive effect on trust. Although the direction of their effect is opposite, age and - to a lesser extent - educational level proved to be the predictors of trust in party and business elite and trust in political and cultural elite. Contrary to our fourth assumption, age and educational level proved to be significant predictors of trust. Age had a negative effect on trust only regarding trust in media, while for all other dimensions it had a positive effect. Young and well-educated people seem to be more critical towards the political system. 


\section{Conclusion}

The first assumption on the multidimensionality of institutional trust was confirmed by factor analysis, which discerned a five-dimensional structure of institutional trust. The five dimensions of institutional trust are: trust in party and business elite, trust in state institutions, trust in cultural elite, trust in the EU and trust in media.

The results did not confirm the hypothesis on trust in media as an independent dimension of institutional trust in Croatia (H2). If we compare results from this study to previous studies, for example with the study of Croatian theologian Stjepan Baloban and sociologist Ivan Rimac's (1999) based on data gathered in 1997 on a nationally representative sample, our data show a similar pattern, even though these studies did not measure the same institutions ${ }^{6}$ and did not use the same scale. Baloban and Rimac (1999), Rimac (2000) and Šporer and Sekulić (2011) used a 4-point scale (1-distrust, 2-little trust and 3-trust a lot, 4-very high trust), while within the 'Trust in Media 2009' project which provides the basis for this paper, a 5-point scale (explained above in this section) was used. The main difference with regard to the level of trust in institutions (taking into consideration the abovementioned methodological and conceptual differences) is the better relative position of national media in the 2009 measurement (Čuvalo, 2011) compared to the 1997 measurement (Baloban \& Rimac 1999). A similar trend was detected by Šporer and Sekulić (2011) who analysed the relationship between citizens' trust in Croatian institutions and corruption (2011) in two waves (the first was in 2004 and the second was in 2010). According to these findings, trust in media in Croatia is not declining (in relation to trust in other institutions). This is different from the declining trends in Western societies (for example, Cook \& Gronke, 2001). The increase in trust in Croatian media can be interpreted as the evidence of an improved performance of the media system at the end of 2000s compared to the situation at the end of first decade of transition (1990s), when the media were criticised due to a strong relationship with politics, especially with respect to the ruling party (HDZ) (Rimac, 2000; Peruško et al., 2011).

Similar to the situation at the end of the 1990s (Mataušić \& Rimac, 2000), Croatian citizens still do not clearly differentiate the media as an independent

\footnotetext{
Baloban and Rimac (1999) used items for the evaluation of trust in different types of media (trust in local radio, trust in Croatian Catholic Radio, trust in state radio, trust in television, trust in independent news magazines and trust in daily newspapers). Rimac (2000) used only one media item, i.e. trust in print, while Šporer and Sekulić (2011) asked respondents to evaluate trust in press and television.
} 
democratic institution. A more detailed analysis of trust in media and trust in other political institutions reveals how the perception of television represents an integral element of trust in state institutions together with trust in government, parliament, police and army, while the perception of radio and weekly magazines constitutes a dimension of trust in party and business elite. These results discern a certain level of political parallelism, which - to Daniel C. Hallin and Paolo Mancini (2004) - is a characteristic of Mediterranean or Polarised Pluralist media systems. According to Peruško (2012), Croatia fits well within this respective model. Another explanation could be that citizens still have difficulties differentiating between media and political institutions and stakeholders as a legacy of an authoritarian past (Mishler \& Rose, 2001).

Contrary to the expected outcome $(\mathrm{H} 3)$, those who watch television more express a higher level of trust in political institutions. The frequency of reading newspapers was not confirmed as significant as regards institutional trust. If we take into consideration the fact that in our case the perception of television is an integral element of trust in political systems, the positive impact of television use on trust is not inconsistent and unexpected. The frequency of consumption of daily newspapers did not confirm to be a predictor of trust in political institutions, which could at least in part be explained by the effect of intermediary variables (such as age and education). Namely, newspaper readers are more frequently older and educated respondents (Čuvalo, 2011), and these two variables, as we show, work in opposite directions. Older respondents have more trust in political institutions, while more educated respondents are more critical. However, multiple regression shows that media use is a better predictor of trust in all tested dimensions when compared to tested socio-demographic indicators. This result discerns in part the importance of media for trust in institutions.

Contrary to our fourth assumption (H4), age and educational level proved to be significant predictors of trust. Age had a negative effect only regarding trust in media, while for all other dimensions age had a positive effect. This is similar to the situation in established democracies (Sztompka, 1999) and to the results that Mishler and Rose (2001) analysed for post-communist countries. This similarity could be explained by the effect of maturation and experience (Sztompka, 1999). Another possible explanation could be that this similar effect has different causes. While in established democracies with a long history of relatively effective democratic institutions trust grows with maturation (and familiarity with the system), in new democracies, older generations evaluate the 
current system as better than the previous (totalitarian or authoritarian) systems. At the same time, young and better educated respondents are more critical towards political systems. High educational level had a negative effect on trust in party and business elite and trust in political and cultural elite, and no significant effect on trust in other dimensions of institutional trust (media, EU, state institutions). Wealth had a positive effect on trust in media and a negative effect on trust in state institutions. The former relationship could be explained by the fact that better educated respondents have more resources and consume more diverse media (Čuvalo, 2011), and consequently have more knowledge and experience as the basis for trust (Sztompka, 1999).

It is important to mention that all presented measures of correlation between respective variables are small, even though some of them are significant. We could assume that the presented analysis and the instruments used as a basis for the analysis did not include some already proven predictors of institutional trust such as values, political orientations, political efficacy, perception of system's performance, etc. Nevertheless, the results at least partly confirm other studies dealing with issues of institutional trust in post-socialist societies (Mishler \& Rose, 2001; Rimac, 2000; Šporer \& Sekulić, 2011), which discern somewhat different patterns of trust than in established democracies. 


\section{References}

Baloban, S. \& Rimac, I. (1999). Povjerenje u institucije u Hrvatskoj. Bogoslovna smotra, 68(4), 663-672.

Beck, U. (1992). Risk Society: Towards a New Modernity. London: Sage.

Car, V. (2011). Televizija u novomedijskom okruženju. Medijske studije, 1(1-2), $40-53$.

Catterberg, G. \& Moreno, A. (2005). The Individual Base of Political Trust: Trends in New and Established Democracies. International Journal of Public Opinion Research, 18(1), 31-48.

Coleman, S. (2012). Believing the News: From Sinking Trust to Atrophied Efficacy. European Journal of Communication, 27(1), 35-45.

Cook, T. E. \& Gronke, P. (2001). The Dimensions of Institutional Trust: How Distinct is Public Confidence in the Media. Chicago: Midwest Political Science Association.

Črpić, I. \& Mataušić, M. (1999). Povjerenje u medije. Bogoslovna smotra, 68(4), 673-683.

Čuvalo, A. (2011). Osobine medijskih publika i povjerenje u medije. Medijske studije, 1(1-2), 40-53.

Dmitrova-Grajzl, V. P. \& Simon, E. (2010). Political Trust and Historical Legacy: The Effect of Varieties of Socialism. East European Politics \& Societies, 24(2), 206-228.

Dohring, H. (1992). Higher Education and Confidence in Institutions: A Secondary Analysis of the "European Values Survey", 1981-83. West European Politics, 15, 126-146.

Giddens, A. (1990). Consequences of Modernity. Cambridge: Polity Press.

Golding, P., Sousa, H. \& Van Zoonen, L. (2012). Trust and the Media. European Journal of Communication, 27(1), 3-6.

Gross, K., Aday, S. \& Brewer, P. R. (2004). A Panel Study of Media Effects on Political and Social Trust after September 11, 2001. The Harvard International Journal of Press and Politics, 9(4), 49-73.

Hallin, D. C. \& Mancini, P. (2004). Comparing Media Systems. Three Models of Media and Politics. Cambridge: Cambridge University Press.

Jones, D. A (2004). Why Americans Don't Trust the Media. A Preliminary Analysis. The Harvard International Journal of Press/Politics, 9(2), 60-75.

Khodyakov, D. (2007). Trust as a Process: A Three-Dimensional Approach. Sociology, 41(1), 115-132. 
Kohring, M. \& Matthes, J. (2007). Trust in News Media: Development and Validation of a Multidimensional Scale. Communication Research, 34(2), 231-252.

Lipset, S. M. \& Schneider, W. (1987). The Confidence Gap. rev. ed. Baltimore: Johns Hopkins University Press.

Luengo, O. G. \& Maurer, M. (2009). A Virtuous Circle for All? Media Exposure and Political Trust in Europe. CONfines, 5(9), 39-48.

Mataušić, M. \& Rimac, I. (2000). Praćenje medija i odnos prema vrednotama. Bogoslovna smotra, (70)2, 485-498.

Mishler, W. \& Rose, R. (2001). What are the Origins of Political Trust? Testing Institutional and Cultural Theories in Post-Communist Societies. Comparative Political Studies, 34(1), 30-62.

Moy, P., Torres, M., Tanaka, K. \& McCluskey, M. R. (2005). Knowledge or Trust: Investigating Linkages between Media Reliance and Participation. Communication Research, 32(1), 58-86.

Newton, K. \& Norris, P. (1999). Confidence in Public Institutions: Faith, Culture or Performance. Annual Meeting of the American Political Science Association, Atlanta, 1-5th September 1999. Accessed 11.03.2013.

URL: http://www.hks.harvard.edu/fs/pnorris/Acrobat/NEWTON.PDF

Newton, K. \& Norris, P. (2000). Confidence in Public Institutions: Faith, Culture, or Performance? In Pharr, S. J. \& Putnam, R. D. (eds.), Disaffected Democracies: What's Troubling the Trilateral Countries?. Princeton, NJ: Princeton University Press, pp. 52-73.

Nikodem, K. \& Črpić, G. (2011). Povjerenje u institucije u Hrvatskoj i Europi $s$ posebnim naglaskom na EU. Paper presented at the conference of Croatian sociological association "Sociology and change -challenges of the future. Zagreb, 7-8. April, 2011.

Norris, P. (ed.) (1999). Critical Citizens. Global Support for Democratic Governance. New York: Oxford University Press.

Norris, P. \& Ingelhart, R. (2009). Cosmopolitan Communications. Cultural Diversity in a Globalized World. Cambridge, New York, Melbourne, Cape Town, Singapore, Sao Paolo, Delhi, Dubai, Tokyo: Cambridge University Press.

Pehlivanova, P. (2009). The Decline of Trust in Post-Communist Societies. Suvremene teme, 2(1), 32-47.

Peruško, Z. (2012). Medijski sustav u Hrvatskoj: od autoritarnog do mediteranskog modela. In Ravlić, S., Puljiz, V., Franičević, V. \& Visković, V. (eds.), 
Hrvatska u Europskoj uniji: kako dalje?. Zagreb: Centar za demokraciju i pravo Miko Tripalo, pp. 437-476.

Peruško. Z. (2011). Stupanj povjerenja publike u medije. In Peruško, Z., Perišin, T., Topić, M., Vilović, G. \& Zgrabljić Rotar, N., Hrvatski medijski sustav. Prema UNESCO-vim indikatorima medijskog razvoja. Zagreb: Fakultet političkih znanost, pp. 111-115.

Quandt, T. (2012). What's Left of Trust in a Network Society? An Evolutionary Model and Critical Discussion of Trust and Societal Communication. European Journal of Communication, 27(1), 7-21.

Pharr, S. J. \& Putnam, R. D. (ed.) (2000). Disaffected Democracies: What's Troubling the Trilateral Countries. Princeton, New Jersey, Sussex: Princeton University Press.

Rimac, I. (2000). Neke determinante povjerenja političkog sustava u Hrvatskoj. Bogoslovna smotra, 70(2), 471-484.

Rimac, I. \& Štulhofer, A. (2004). Sociokulturne vrijednosti, gospodarska razvijenost i politička stabilnost kao čimbenici povjerenja u Europsku Uniju. In Ott, K. (ed.), Pridruživanje Hrvatske Europskoj Uniji. Izazovi institucionalnih prilagodbi, 2. Sv. Zagreb: Institut za javne financije, Zaklada Friedrich Ebert, pp. 287-312.

Sztompka, P. (1999). Trust: A Sociological Theory. Cambridge University Press. Cambridge.

Šalaj, B. (2006). Socijalno povjerenje: Hrvatska 1995-2003. Anali hrvatskog politološkog društva, 2(1), 35-56.

Šporer, Ž. \& Sekulić, D. (2011). Gubimo li povjerenje u institucije. In Kregar, J., Sekulić, D. \& Šporer Ž, Korupcija i povjerenje. Zagreb: Centar za demokraciju i pravo Miko Tripalo and Pravni fakultet Sveučilišta u Zagrebu, pp. $71-117$.

Trzun, Z. (2012). Kriza povjerenja u institucije: istraživanje povjerenja u vojsku. Polemos, 15(1), 33-54.

Tsfati, Y. \& Cappella, J. N. (2003). Do People Watch What They Do Not Trust?: Exploring the Association between News Media Skepticism and Exposure. Communication Research, 30(5), 503-529.

Thompson, M. (1995). The Media and Modernity. Oxford: Polity Press. van Zoonen, L. (2012). I-Pistemology: Changing truth claims in popular culture and political culture. European Journal of Communication, 27(1), 56-67. 